\title{
Race, class and
}

\section{violent crime in}

South Africa

\section{Dispelling the 'Huntley thesis'}

\section{GAVIN SILBER AND NATHAN GEFFEN}

gavinsilber@gmail.com

nathan@tac.org.za

Brandon Huntley was granted asylum in Canada earlier this year based on the argument that whites are disproportionately affected by crime in South Africa. The decision was generally condemned, but it did receive support from various groups and individuals including Afriforum, the Freedom Front and James Myburgh (editor of Politicsweb). In this article we show the flaws in Huntley's argument by presenting evidence from several sources that demonstrate that black and poor people are disproportionately the victims of violent crime in South Africa. We are concerned that painting whites as the primary victims of South Africa's social ills is unproductive, ungenerous and potentially hampers the appropriate distribution of resources to alleviate crime. Furthermore, in order to move the debate on crime in South Africa into a more productive direction, we also describe the Social Justice Coalition (SJC) - a relatively new community based organisation that aims to mobilise communities around improving safety and security for all in South Africa, regardless of race or income. Campaigning for novel pragmatic and coordinated community and government responses to the broader lack of safety and security in the country, the SJC focuses on the introduction and development of basic infrastructure and services as a means of reducing crime.

Everyone in South Africa is affected by crime, and the consequent sense of insecurity that comes with living in fear. Some encounter it directly, others through the experiences of friends and family, and just about all of us through news media, which routinely reminds us of the abundant violence that has come to characterise our society. Yet despite this collective concern, far too little has been done both to mobilise people across class, gender, national and racial barriers to advocate for improved crime reduction strategies; and to call on all people in South Africa to contribute personally towards creating safer communities. The recent case of South African Brandon Huntley, who earlier this year received refugee status in Canada, has exposed the divided perceptions of crime across race and class. Huntley's lawyers reportedly convinced an immigration review board that 'the ANC government was failing to protect the white minority from criminal violence perpetrated by black South Africans'. ${ }^{1}$ Consequently, 142 academics signed an open letter to the Charge d'Affaires of Canada in South Africa denouncing the decision, stating,

The outrageously distorted representation of contemporary South Africa does not square with the realities in our country, by any factual measure. While the crime rates in South Africa 
are high as a consequence of numerous interrelated factors - many of which are the working through of the past brutalization of our society by the system of white supremacy, and none of which relate to inherent criminal tendencies in black people - it is simply untrue that white people are being targeted disproportionately. Black South Africans are much more likely to be victims of crime, largely because they are less able to afford the protections and security measures which most white South Africans, as still privileged citizens, are able to acquire. ${ }^{2}$

But Huntley's argument was sympathetically received by many in the white community. The Freedom Front Plus stated, 'For the ANC to label the decision of Canada to grant the South African, Brandon Huntley, asylum status, as racist, is in itself racist. ${ }^{\prime 3}$ Afriforum is considering intervening as an amicus (friend of the court) in support of Huntley if his case is appealed. ${ }^{4}$ James Myburgh, the editor of Politicsweb (a popular political news and opinion website) has disputed the facts of the academics' open letter. He uses the findings of victimisation surveys to argue that contrary to the claim made in the open letter, it is in fact whites - and lately Indians - who are disproportionately affected by crime. Myburgh's argument is the most articulate presentation of what we call the Huntley Thesis: the argument that whites are disproportionately affected by crime (perpetrated by blacks).

In what follows, we present evidence suggesting that Myburgh and the advocates of the Huntley thesis are most likely wrong. We cannot definitively disprove it, because data on crime are incomplete and insufficiently categorised by race. Nevertheless, the available evidence, as far as we can determine, shows that although all races and classes in South Africa are unduly affected by crime, black and poor people are disproportionately affected. ${ }^{5}$ Myburgh questions why 'over a hundred of our top academics appended their signature to a document without (apparently) interrogating its factual accuracy?'6 We show that it was reasonable for the academics' letter to state that 'black and poor people are much more likely to be victims of crime,' particularly if one infers, reasonably, that they were referring to serious and violent crime.

It would be fair to assert that the vast majority of society acknowledges that crime affects all races and classes, but it is also our duty to acknowledge that it affects some more than others. We can think of two reasons for making this point. Firstly, it has a bearing on where resources for alleviating crime should be concentrated. Currently financial resources for the crime response (much of it private approximately R46 billion per year ${ }^{7}$ ) are primarily spent on affluent areas. Secondly, the view that whites are being disproportionately victimised needs to be debunked. Whites are not the primary victims of South Africa's social ills, and propagating the view that they are encourages ungenerous politics that refuses to acknowledge the responsibility whites have to address past wrongs. This is epitomised by Huntley's case.

\section{WORKING TOGETHER TO CREATE SAFER COMMUNITIES}

The use of populist rhetoric and unsubstantiated claims when addressing the issue of crime - or any other social issue, for that matter - is dangerous and irresponsible. It fosters a deep fear and mistrust along class and racial lines and ignores the legacy left by apartheid. It hampers integration, promotes racism (amongst black and white), and supports inequality - all of which often morph into the fear and contempt that ultimately leads to the failure of individuals and the state to discuss and address the root causes of critical social issues.

A new approach in garnering productive community and state responses to crime is currently being piloted by the Western Capebased Social Justice Coalition (SJC), a grassroots organisation formed in 2008 as a response to the xenophobic violence and subsequent displacement and mistreatment of thousands of immigrants. Its membership has grown steadily, 
and includes people from an array of economic and racial backgrounds, stretching from Green Point - the well known, gentrified and affluent 2010 World Cup host suburb - to Khayelitsha, a lesser known and underdeveloped poor working class area. The 20 kilometres separating these two areas are relatively inconsequential for they are truly worlds apart, yet the respective residents regularly sit down together to discuss their concerns, most of which are shared.

One year on, the SJC focuses on working towards safety and security for all - citizen and immigrant, white and black, rich and poor. The SJC's campaign work is fundamentally based on the understanding that ensuring safety and security requires active citizens and communities, an understanding of the law and its application, and a more pragmatic state approach than the oftheld disproportionate focus on criminal justice. Improving the quality of the justice system and police service is understood to be important, but street lights, access to proper ablution facilities, after school child care, and pedestrian friendly streets can significantly improve the lives of many, and lead to a lower incidence of exposure to crime. Community members engage with each other, local policy makers and members of the legal/policing fraternity on a regular basis through lectures, workshops, awareness drives and campaign work.

The bulk of the SJC's membership resides in Khayelitsha, where just 38 per cent of inhabitants live in what are loosely defined as 'formal structures', ${ }^{8} 20$ per cent live with immediate access to water, 65,1 per cent with access to flush/chemical toilets, and a significant number without electricity ${ }^{10}$ Unemployment is currently estimated at over 50 per cent. ${ }^{11}$ Very few homes are serviced by functioning streets or lighting; and the landscape constantly changes due to flooding, fires and migrant labourers looking for work in the city, rendering it difficult to protect residents and police the area.

The SJC's provincial office in Khayelitsha attempts to actively assist victims of crime and poverty on a daily basis. Women are frequently beaten and raped walking to the toilet or fetching water from taps not more than 50 metres from their homes, children are routinely injured or killed by cars and taxis that hurtle through their backyards, alcohol abuse is rife, illness and death from waterborne diseases such as diarrhoea are common, houses are frequently lost to fire and flooding, and contact crime is ever present. These burdens pervade every crevice of a township that is overwhelmingly black and poor, ${ }^{12}$ but are often accepted as being part of everyday life. Little faith or trust is instilled in the police or the courts and residents see the situation as being impervious to any response instigated by government or the community.

The inadequate provision of these and other basic amenities, along with failures in the criminal justice system, serves to exacerbate the broader deficit in safety and security, and results in several constitutional rights being routinely violated (this is true everywhere but particularly in poor areas). For instance: Section 12 of the Bill of Rights, which refers to freedom and security of the person, calls for all 'to be free from all forms of violence from either public or private sources'. ${ }^{13}$ The sense of insecurity and heightened risk levels in Khayelitsha contribute to the broader generation of victims and perpetrators of violent crime.

Our arguments against Myburgh's articulation of what we have called the Huntley thesis follow below.

\section{GAUGING THE DISTRIBUTION OF CRIME}

Myburgh relies on national victimisation surveys (NVSs) produced by the Human Sciences

Research Council (HSRC) ${ }^{14}$ Institute for Security Studies (ISS), ${ }^{15,16}$ and Markinor ${ }^{17}$ as the fundamental basis of his argument.

Michael O'Donovan, author of a paper on the ISS's most recent NVS (cited by Myburgh), notes how 'opinion surveys cannot, by any stretch of the imagination, provide an objective measure of changes in crime rates', ${ }^{18}$ and that they are important insofar as they reflect 'respondents' 
beliefs'. It is imprudent for researchers or policy makers to rely solely on these methods and results to estimate the extent and nature of crime.

Numerous contradictions between opinions and reality routinely arise that warn against using such data irresponsibly. As O'Donovan points out, these '[contradictions] point to the limits of generalising victimisation surveys to the population as a whole. ${ }^{19}$

Taking simplified snapshots from victimisation surveys will ultimately fail to provide an adequate yardstick or gauge of the distribution of crime. By extension, using opinions to extrapolate the extent of actual crime (by using 'crime' as a uniform variable) will always fail to distinguish between serious violent crime and less invasive propertyrelated crime. Practitioners of these surveys assert that differentiation does take place, but the inclusion of sample questions that ask whether someone has been a 'victim of crime' - as included in the 2007 ISS and Markinor surveys can be very misleading when used in isolation. Myburgh's analysis thus fails to differentiate between crime categories (and the severity thereof); assumes that respondents are homogenous and equally responsive to questioning; and uses such findings as evidence to argue that particular groups are being disproportionately affected. There is sufficient additional evidence to doubt the ability of NVSs to support this conclusion.

Firstly, the very concept of crime or criminality can be relatively subjective, as indeed is the case with 'victimhood'. Some respondents to NVSs classify the threat of violence as a criminal act, while others might only classify its use as criminal. ${ }^{20}$ In addition, the distinction between perpetrator and victim can also be somewhat blurred in cases such as assault.

Secondly, there is strong evidence showing that reported victimisation levels tend to increase with education, which is obviously (and particularly in South Africa) linked to income. A study in the United States showed that people with university degrees recalled three times as many assaults as those with a high school education. ${ }^{21}$ It is conceivable that over-exposure to a particular crime category amongst certain NVS respondents (in this case people with little education) may result in lesser infringements - such as assault not qualifying as 'criminal'. This has also been observed in studies illustrating how various developed cities/countries have produced higher victimisation rates than poorer countries with higher levels of recorded crime. ${ }^{22}$

Thirdly, reporting of property-related and violent crime tends to differ significantly, based on various circumstances. When a given sample is questioned on exposure to violent interpersonal crimes such as assault and sexual abuse (particularly when it involves a non-stranger), the results are likely to reflect a significant underreporting of actual exposure, due to a reluctance to report sexual abuse, child abuse, general assault and domestic violence.

Moreover, there might be differences in the way poor and relatively wealthy respondents perceive property-related crime. Relatively wealthy people have more items of value, and are able to afford insurance, which requires reporting such crimes to the authorities. This might mean they are more likely to be conscious of, or remember, thefts they have experienced in the period covered by the NVS.

We think it fair to conclude that, while victimisation surveys provide some illustration of the level of fear and the extent of crime as a loosely defined variable, they cannot be used on their own to conclude who is worst affected and by extension, which group is most in need of intervention. They might work to a very limited extent with regard to property crime, but are unable to adequately shed light on incidence of assault, attempted murder and sexual abuse.

\section{WHAT THE STATISTICS TELL US}

We have looked at several sources in an attempt to break down crime by race. Given the impossible task of accurately quantifying the level of serious crimes (including sexual offences and assault) using official statistics - due both to under- 
reporting and poor or unavailable police data the best indicator we have to gauge the level of violent crime is death by non-natural causes, and homicide rates in particular. And while assaults and even attempted murders may often go unreported, very few murders do.

In 2008/2009 18148 people in South Africa were murdered. This amounts to 37,3 people per 100000 , or just under 50 per day..$^{23}$ The evidence we have examined indicates that the victims are disproportionately African and coloured working class people. Young men are also disproportionately represented in the murder statistics. We examined Statistics South Africa (Stats SA) mortality data to determine the breakdown of murders by race. Our analysis is inconclusive but it indicates that victims are disproportionately Africans and coloureds.

Stats SA has released several mortality reports since 2000, one of which provides data on unnatural deaths broken down by race. ${ }^{24}$ This report published the results of a detailed analysis of a 12 per cent sample of death notification forms from 1997 to $2001 .^{25}$

There is no specific murder category. Instead we examined unnatural deaths, which includes murders, suicides, motor accidents, poisonings, etc. The largest category of unnatural deaths is unfortunately titled 'Unspecified'. Until 2000 'unspecified' was the largest cause of death overall, after which it was overtaken by AIDS. Table 1 shows the percentage contribution to the South African population for each race during this period. Table 2 shows the unspecified unnatural deaths broken down by race in the sample. As can be seen, the race groups are affected by crime in approximately equal proportion to their contribution to population. However, the data are very limited because an additional 13946 unspecified unnatural deaths, i.e. 45 per cent, were classified as 'other or unknown' race.

Nevertheless, one category of unnatural death does indeed shed light on the relative
Table 1: Percentage contribution to South African population for each race 1997-200126

\begin{tabular}{l|c|}
\hline Race & \% contribution \\
\hline African & 76,7 \\
\hline Coloured & 8,9 \\
\hline Indian & 2,6 \\
\hline White & 10,9 \\
\hline
\end{tabular}

Source: Stats SA

Table 2: Contribution by race towards unspecified unnatural deaths 1997-2001

\begin{tabular}{l|r|c|}
\hline Race & & \% contribution \\
\hline African & 13100 & 78,06 \\
\hline Coloured & 1730 & 10,31 \\
\hline Indian & 325 & 1,94 \\
\hline White & 1627 & 9,69 \\
\hline TOTAL & 16782 & 100 \\
\hline
\end{tabular}

Source: Stats SA

Table 3: Male deaths by assault 1997-2001

\begin{tabular}{l|r|c|}
\hline Race & & \% contribution \\
\hline African & 1230 & 81 \\
\hline Coloured & 209 & 14 \\
\hline Indian & 18 & 1 \\
\hline White & 54 & 4 \\
\hline TOTAL & 1511 & 100 \\
\hline
\end{tabular}

Source: Stats SA

proportion of murders per race group: death by assault.

Table 3 shows deaths by assault for males broken down by race. This shows that African and coloured men are disproportionately affected. However, again an additional 432 deaths in this category were classified as 'other or unknown' race.

Myburgh quotes what he regards as a racist statement towards whites by the late Dullah Omar in February 1999. He then writes: 'It is an open question whether [the ANC's] racialist propaganda would have given the green light to criminals to cross over the colour line en masse. ${ }^{27}$ 
It is far-fetched to imply that an obscure statement by a minister would have been sufficient to encourage cross-racial crime. But furthermore, evidence from the Stats SA report shows this cannot be the case. Unnatural deaths are decreasing, or at worst stabilising (and this is confirmed by follow-up Stats SA reports and police murder statistics) amongst all groups. Myburgh's implied theory of increased attacks on whites due to the ANC's racial rhetoric is consequently unfounded.

More compelling data come from the Medical Research Council (MRC). In an investigation into female homicide rates in South Africa in 2004, ${ }^{28}$ the MRC used national mortuary data to determine that 2,8 of every 100000 white women die as a result of murder, whereas 8,9 Africans and 18,3 coloureds meet the same fate. This shows, that at least for women, Myburgh is very likely wrong and the academics are right. Black women are disproportionately murdered.

Another recent study by the Centre for The Study of Violence and Reconciliation (CSVR) analysed homicide rates in high-risk areas in KwazuluNatal, Western Cape, and Gauteng, ${ }^{29}$ using a representative sample of police dockets. Of the sample 85 per cent of homicide victims were black, nine per cent were coloured, five per cent Asian and one per cent of victims were white.

\section{CAPE TOWN: A CASE STUDY}

\section{Cape Town is the South African city that best} exemplifies the uneven distribution of resources that renders this country one of the least equal societies in the world in terms of income. ${ }^{30}$ Its demography is stratified more than any other city along geographic lines - a remnant of the Group Areas Act. It also happens to fall into one of the most violent provinces in the country, and is the city in which Huntley resided. We have analysed Cape Town's crime data to illustrate the extent of serious and violent crime, and who is most affected by it.

A recent study carried out by the City of Cape Town $^{31}$ contains a breakdown of crimes under investigation by each police district in the year 2007/2008. The results indicate a significant disparity between homicide and rape cases in lowincome areas when compared to wealthier and traditionally white communities. It was found that of the 58 police districts in the city, five police districts account for over 44 per cent of murders Nyanga (13,18 per cent), Harare Khayelitsha $(8,67$ per cent), Khayelitsha (8,47 per cent), Gugulethu (7,58 per cent), and Delft/Belhar (6,1 per cent). ${ }^{32}$ This is illustrated graphically in Figure 1.

A similar scenario emerges with rape cases: Five police districts account for 34 per cent of reported rape cases, Nyanga (7,97 per cent), Harare $(6,91$ per cent), Mitchell's Plain (6,83 per cent), Khayelitsha (6,75 per cent) and Delft/Belhar (5,28 per cent). ${ }^{33}$ This is illustrated graphically in Figure 2.

Looking at these graphic representations we can immediately tell that for both rape and murder, the lowest number of reported cases occurs along the Atlantic Seaboard (Camps Bay, Sea Point, etc); and along a corridor of affluence that stretches from Simon's Town in the south to the prosperous southern suburbs (Constantia, Claremont, etc.), and then east through the northern suburbs to the city limit. There is indeed a higher incidence of rape and murder cases in certain areas in the northern suburbs that include middle-class white and coloured suburbs, but this can be explained by the fact that they are large geographic areas that also include large poor and working class communities.

Property crime is the exception to the rule, although rather than targeting whites or minority groups (as argued by Huntley and Myburgh), perpetrators tend to target areas that are economic hubs, and areas that are adequately saturated with consumers. The main areas affected by business crimes include the city centre, Bellville, Mitchell's Plain and Parow - all of which have numerous shopping centres and businesses and vary in terms of racial composition.

When using another dataset compiled by the MRC in cooperation with the City of Cape Town ${ }^{34}$ 
to conduct a broader analysis by sub-district, considerable disparities in the rates of fatal injuries occur across all categories (Figure 3). Most striking is the comparison of homicide rates - from the relatively low levels of under 26,1/ 100000 population in the southern district to 110,5/100 000 in Khayelitsha. The former encompasses some of Cape Town's wealthiest residents and a large white population, while the latter contains some of its poorest residents, and is predominately black. These areas also correspond in terms of the lowest and highest rates of road traffic fatalities, which further highlights the effect that a lack of physical infrastructure can have on community safety.

\section{CONCLUSION}

As we have emphasised, the data are incomplete and the evidence not conclusive. Nevertheless, the available evidence indicates that the burden of serious crime is disproportionately absorbed by black and poor South Africans. Brandon Huntley's argument to Canadian immigration authorities is not supported by available facts.

Fighting over resources is unlikely to produce positive results for anyone, but it is our duty to acknowledge the realities of our past and present if we are to succeed in creating a safe and secure future for all people living in South Africa.

Figure 1: Spatial distribution of reported murders by police precinct $(2007 / 08)^{35}$

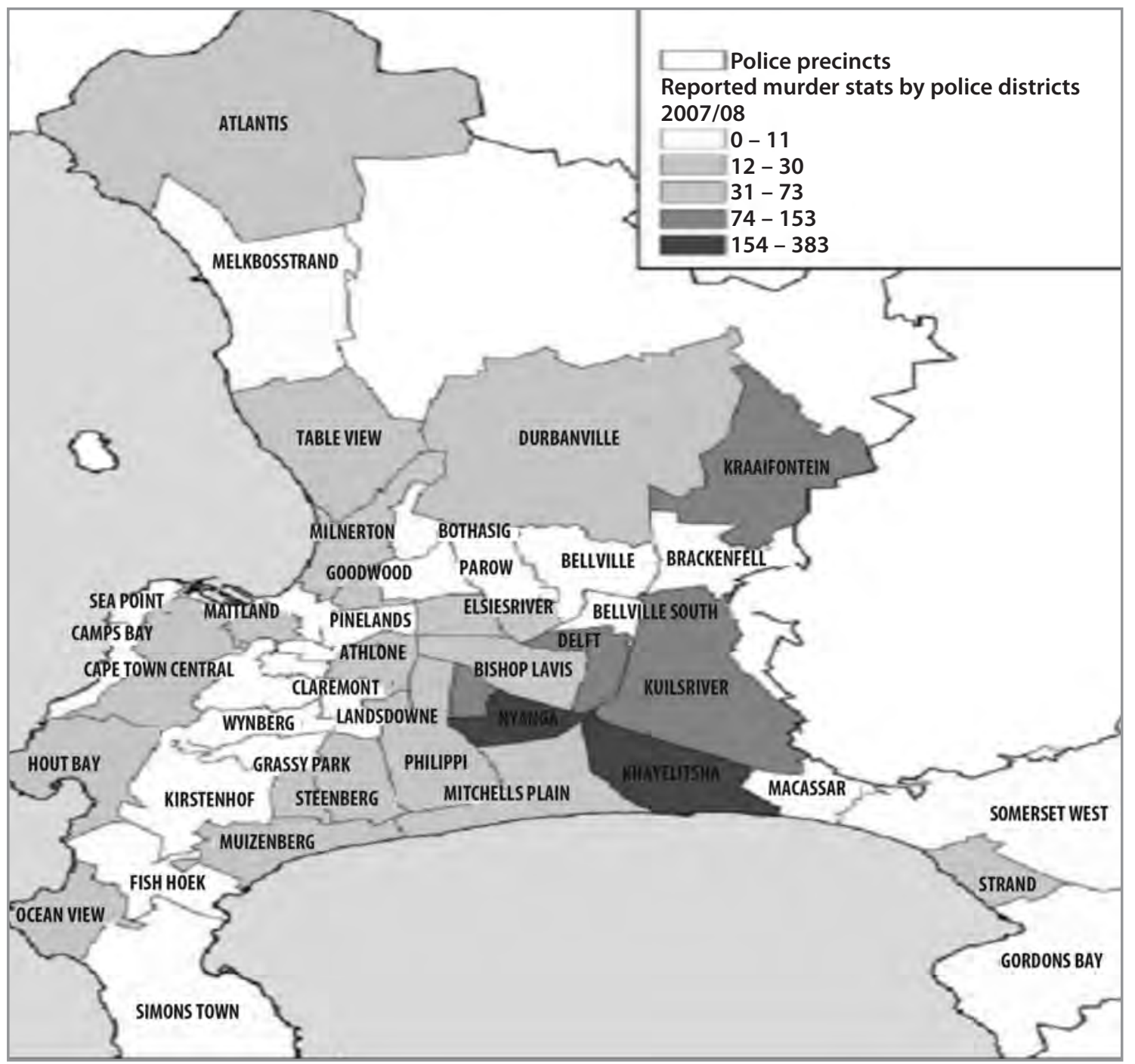


Figure 2: Spatial distribution of reported rape by police precinct (April to December 2007)

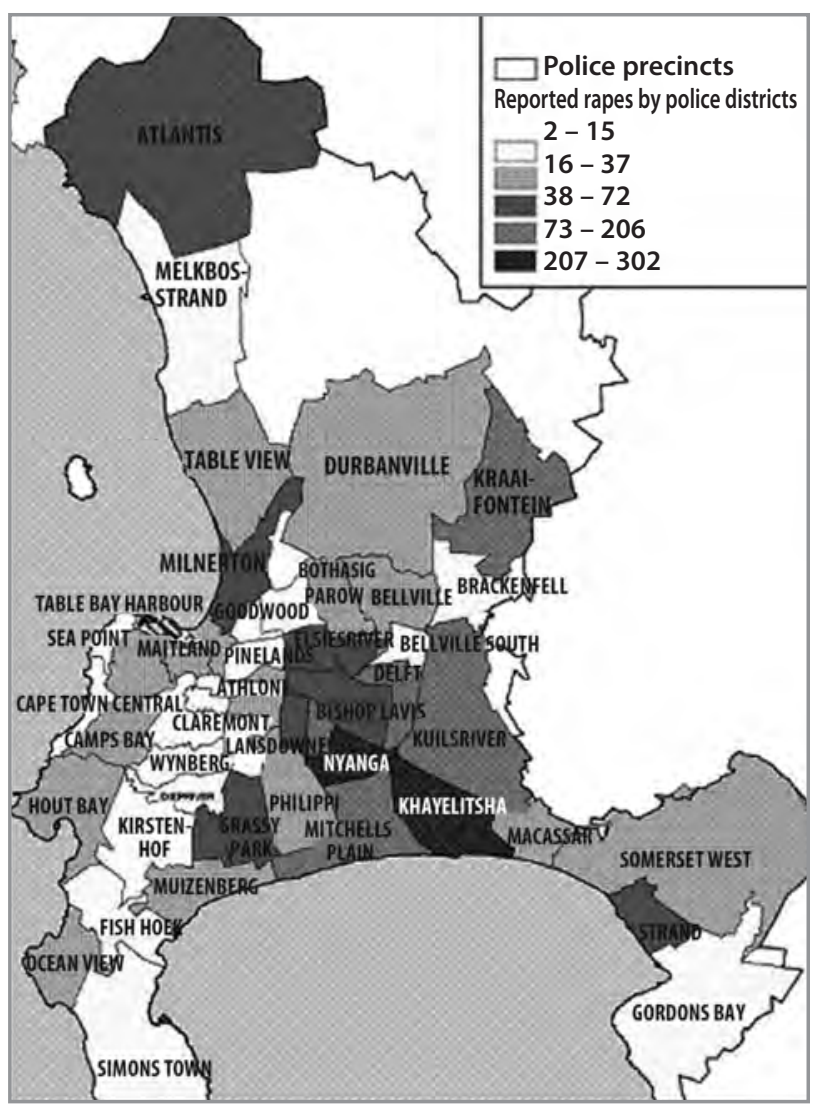

Figure 3: Age-standardised death rates (pooled estimates) due to injuries by sub-district, Cape Town $2003,2004,2006^{36}$

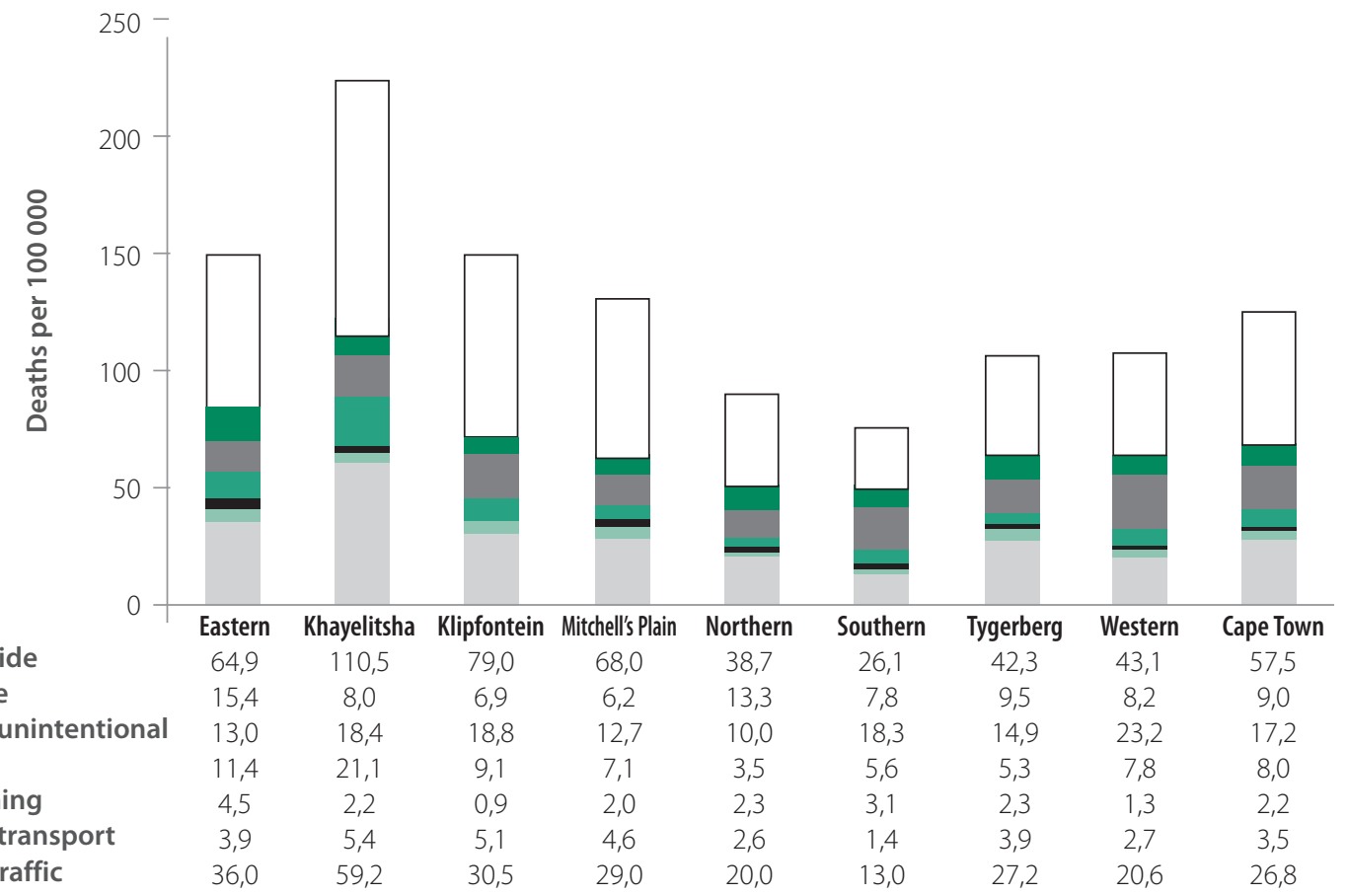


To comment on this article visit

http://www.issafrica.org/sacq.php

\section{NOTES}

1 J Myburgh, Did 142 academics \& others get it wrong on crime, 2009, http://www.politicsweb.co.za/ politicsweb/view/politicsweb/en/page71619?oid=14347 5\&sn=Detail (accessed 15 October 2009).

2 Open letter to the Charge d'Affairs of Canada in South Africa (undated). Available at http://www.politicsweb.co.za/view/politicsweb/en/page 71651 ? oid $=143169 \&$ sn $=$ Detail (accessed 17 November 2009).

3 Freedom Front Plus Statement on Politicsweb. ANC

Racist About Asylum Status in Canada - FF+, http://www.politicsweb.co.za/politicsweb/view/politics web/en/page 71619 ? oid $=141668 \&$ sn $=$ Detail (accessed 10 October 2009).

4 Afriforum Statement on Politicsweb: Afriforum Seeks To Intervene In Canada Asylum Case, http://www.politicsweb.co.za/politicsweb/view/politics web/en/page71619?oid=142486\&sn=Marketingweb + det ail (accessed 10 October 2009).

5 Ninety per cent of people under the poverty line (earning less than R924pm) are black.

6 B Holtmann, Breaking the Cycle of Crime and Violence: Essential Steps to a Safe South Africa, 2009, http://www.safesouthafrica.org.za/the-model.html (accessed 13 October 2009).

7 Myburgh, Did 142 academics \& others get it wrong on crime.

8 Sub-Directorate Population Development in the Research and Population Directorate Department of Social Services and Poverty Alleviation, The Population Register Update: Khayelitsha, 2006.

9 Statistics SA, Census 2001: Census in Brief, 2001.

10 Ibid.

11 City of Cape Town data referred to in Poswa and Levy, Migration study in Monwabisi Park (Endlovini), Khayelitsha, City of Cape Town, 2006.

12 Statistics SA, Census 2001: Census in Brief.

13 South African Constitution, Bill Of Rights, Section 12, 1996.

14 R Humphries, Crime, National Opinion Survey, Human Sciences Research Council, 1999.

15 B Burton et al, National Victims of Crime Survey South Africa 2003, ISS Monograph 101, July 2004.

16 National Victimisation Survey, Institute for Security Studies, 2007.

17 M Harris \& S Radaelli, Paralysed by fear: Perceptions of crime and violence in South Africa, SACQ 20 (2007).

18 M O'Donovan, South Africans' perceptions of the police and the courts: Results of the 2007 National Victims of Crime Survey, ISS Occasional Paper 176, December 2008.

19 Ibid.

20 Ibid.

21 W Grove et al, Are Uniform Crime Reports a Valid Indicator of the Index Crimes? An Affirmative Answer with Minor Qualifications, Criminology 23 (3) (1985).

22 Ibid.

23 SAPS, 2009 at http://www.saps.gov.za/saps_profile/ strategic_framework/annual_report/2008_2009/ 2_crime_situation_sa.pdf

24 Causes of death in South Africa 1997-2001: Advance release of recorded causes of death, Stats SA: 2002.

25 Nathan Geffen used this report to debunk Rian Malan and, by proxy, President Mbeki's pseudoscientific views on AIDS statistics. See http://www.tac.org.za/ newsletter/ 2004/ns20_01_2004.htm (accessed 20 October 2009)

26 Myburgh, Did 142 academics \& others get it wrong on crime.

27 State of South Africa's Population Report 2000, 73, http://www.info.gov.za/otherdocs/2000/population.htm (accessed 20 October 2009).

28 S Mathews et al, A National Study of Female Homicide in South Africa, MRC Policy Brief 5, 2004.

29 Streets of Pain, Streets of Sorrow, CSVR, 2008.

30 H Bhorat, Business Report 2009, http://www.busrep. co.za/index.php?fSectionId $=552 \&$ fArticleId $=5181018$ (accessed 15 October2009)

31 J Gie, Crime in Cape Town: 2001-2008, A brief analysis of reported Violent, Property and Drugrelated Crime in Cape Town, City of Cape Town, 2009.

32 Ibid.

33 Ibid.

34 P Groenewald et al, Cause of death and premature mortality in Cape Town, 2001-2006. Cape Town: South African Medical Research Council, 2008.

35 Gie, Crime in Cape Town: 2001-2008.

36 Groenewald et al, Cause of death and premature mortality in Cape Town, 2001-2006. 